preferentially cleaved all of these mutant RNAs at positions G4, G24 and G27 (Fig. 4a), which are the same sites cleaved in native RNA I and in the GGG.RNA I variant ${ }^{14}$. However, the relative intensity of bands representing cleavage products was greatly reduced for RNA I. $\Delta 50$, suggesting that this RNA exists in a conformation that shields the single-stranded 5 ' segment and the loop of stem-loop I from cleavage by RNase $T_{1}$. Similarly, RNase E cleavage, which occurred in all of these RNA variants at the site cleaved in wild-type RNA I, was sharply decreased for RNA I. $\Delta 50$ (Fig. $4 b$ ). RNase E cleavage of RNA I. $\Delta 42$ was also reduced, although not to the same extent as cleavage of RNA I. $\Delta 50$ (Fig. $4 b$ ). These results suggest that overall substrate conformation influences the accessibility of RNase E, and other ribonucleases to potentially cleavable sites. However, in contrast to the effects we observed for RNase E and RNase $T_{1}$, the rate of cleavage by $R N a s e V_{1}$, which was used to confirm the integrity of the stem-loop adjacent to the R Nase E cleavage site, was not affected by the mutations we studied (data not shown).

Our findings indicate that stem-loop regions in RNA I impede, rather than promote, RNase E cleavages, and that other modifications that affect higher-order structure can further reduce cleavage at susceptible sites. As RNase E does not require a stem-loop for entry to a substrate (this study) or a particular order of nucleotides ${ }^{12,13}$, many $(\mathrm{A}+\mathrm{U})$-rich sequences within complex RNAs are likely to contain sequences that can be cleaved, provided that the sequences are unpaired and are otherwise accessible to the enzyme. Stem-loop regions or alterations in overall substrate conformation may interfere with RNase E cleavages by limiting access of the enzyme. Additionally, our discovery that R Nase E can attack short RNA oligomers raises the possibility that this endonuclease, which initiates the processing of ribosomal RNA precursors and the decay of a variety of other $E$. coli transcripts ${ }^{2} 5$, may also cut (at sites made available by the removal of regions of secondary structure) some of the fragments that it and other ribonucleases have generated by previous cleavages. Thus, RNase E cleavage resulting in or following stem-loop removal may occur reiteratively during the decay and processing of complex transcripts in vivo. If this is correct, the prolonged chemical half-life observed for bulk RNA and individual mRNA transcripts when RNase $\mathrm{E}$ activity is mutationally limited ${ }^{16.17}$ may reflect a decrease in endonucleolytic cleavage of decay intermediates as well as a reduced rate of cleavage of primary transcripts.

Received 9 December 1994; accepted 24 January 1995.

1. Misra, T. K. \& Apirion, D. J. biol. Chem. 253, 5594-5599 (1978).

2. Ehretsmann, C. P., Carpousis, A. J. \& Krisch, H. M. FASEB J. 6, 3186-3192 (1992).

3. Melefors, O., Lundberg, U. \& von Gabain, A. in Control of Messenger RNA Stability (eds Belasco, J. \& Brawerman, G.) 53-70 (Academic, San Diego, 1993).

4. Higgins, C. F. Peltz, S. W. \& Jacobson, A. Curr. Opin Genet. Dev, 2, 739-747 (1992)

5. Apirion, D. Miczak, A. \& Taraseviciene, L. Molec. Biol, (Life Sci. Adv) 11, 221-233 (1992).

5. Apirion, D., Miczak, A. \& Taraseviciene, L. Molec. Biol. (L

7. Mackie, G. A. J. biol. Chem. 267, 1054-1061 (1992).

8. Cormack, R. S. \& Mackie, G. A. J. molec. Biol. 228, 1078-1090 (1992)

9. Ehretsmann, C. P., Carpousis, A. J. \& Krisch, H M. Genes Dev. 6, 149-159 (1992)

10. Mackie, G. A. \& Genereaux, J. L. J. molec. Biol. 234, 998-1012 (1993)

11. Tomcsanyi, T. \& Apirion, D. J. molec. Biol. 185, 713-720 (1985).

12. Lin-Chao, S., Wong. T. T., McDowall, K. J. \& Cohen, S. N.. J. biol. Chem. 269, 10797-10803 (1994).

3. McDowall, K. J., Lin-Chao, S. \& Cohen, S. N. J. biol. Chem. 269, $10790-10796$ (1994).

14. Helmer-Citterich, M., Anceschi, M. M., Banner, D. W. \& Cesareni, G. EMBO J. 7, 557-566 (1988).

15. Takahashi, K. J. Biochem. 49, 1-8 (1961).

16. Apirion, D. \& Lassar, A. B. J. biol. Chem. 253, 1738-1742 (1978)

17. Ono, M. \& Kuwano, M. J. molec. Biof. 129, 343-357 (1979)

18. Tamm, J. \& Polisky, B. Nucleic Acids Res. 11, 6381-6397 (1983).

19. Tamm, J. \& Polisky, B. Nucleic Acids Res. 11, 6381-6397 (1983).

20. Hochuli, E., Dobeli, H. \& Schacher, A. J. Chromat. 411, 177-184 (1987).

20. Hochuli, E., Dobeli, H. \& Schacher, A. J. Chromat. 411, 177-184 (1987).
21. Lin-Chao, S. Chen, W. T. \& Wong. T. T. Molec. Microbiol. 6, 3385-3393 (1992).

21. Lin-Chao, S., Chen, W. T. \& Wong, T. T. Molec. Microbiol.

22. Goidbium, K. \& Apirion, D. Cell 15, 1055-1066 (1981).
23. Lin-Chao, S. \& Cohen, S. N. Cell 65, 1233-1242 (1991)

24. Tucker, W. T., Miller, C. A. \& Cohen, S. N. Cell 38, 191-201 (1984).

ACKNOWLEDGEMENTS. This research was supported by grants from the National Science Council (N.S.C) of the Republic of China to S. L.C. and S.N.C. and from the U.S. National Institutes of Health to S.N.C. K.J.M. and V.R.K. received postdoctoral fellowships from the Science and Engineering Research Council of the United Kingdom and the N.S.C., respectively. SUPPLEMENTARY INFORMATION. Requests should be addressed to Mary Sheehan at the London office of Nature.
ERRATUM

\section{Interaction with RAP74 subunit \\ of TFIIF is required for \\ transcriptional activation \\ by serum response factor}

Véronique Joliot, Mark Demma \& Ron Prywes

Nature 373, 632-635 (1995).

IN the contents page for the 16 February issue the title for this Letter included an error (TFIID for TFIIF) which could cause confusion. The Letter itself was printed correctly.

\section{CORRECTIONS}

\section{$\gamma$-Interferon and expression of \\ MHC genes regulate peptide hydrolysis by proteasomes}

\author{
Maria Gaczynska, Kenneth L. Rock \\ \& Alfred L. Goldberg
}

Nature 365, 264-267 (1993)

THE caption to Fig. 1, page 265, lines $13 \cdots 15$, should have stated "one unit represents one $\mu \mathrm{mol}$ substrate cleaved per $\mathrm{mg}$ protein per hour" (not one nmol), and on lines 2324 , " $K_{\mathrm{m}}$ values of $0.4 \mathrm{mM}$ and $0.5 \mathrm{mM}$ " (not $\mathrm{nM}$ ). Unfortunately, these typographical errors have led Ustrell et al. to argue that our findings were invalid, based on their incorrect impression that our kinetic values for proteasome varied widely between experiments and differed sharply from values obtained by others. However, calculations of the $V_{\max }$ and $K_{\mathrm{m}}$ from Figs 1 and 2 using the correct units yield values that resemble those in our other experiments (Tables 1-3) and fall within the range of values obtained by Ustrell et al. ${ }^{1}$, by others ${ }^{2-4}$, and in our own subsequent work ${ }^{5}$. Moreover, the central finding in our paper (that $\gamma$-IFN alters the peptidase properties of the proteasome through the incorporation of the MHC-encoded subunits) has been confirmed in six different cell lines by three independent laboratories ${ }^{6}{ }^{8}$, and also by our subsequent studies involving the transfection ${ }^{5}$ or deletion of the LMP genes ${ }^{9}$.

1. Ustrell, V., Pratt, G. \& Rechsteiner, M.. Proc. natn. Acad. Sci. U.S.A. 92, 584-588 (1995)

2. Ma,C. P.. Slaughter, C. A. \& DeMartino, G. J. biol. Chem. 267, 10515-10523 (1992)

3. Rivett, A. J. J. biol. Chem. 264, 12215-12219 (1989)

4. Boes, B et al. J exp. Med 179, 901-909 (1994).

5. Gaczynska, M., Rock, K. L., Spies, T. \& Goldberg, A. L. Proc. natn. Acad. Sci. U.S.A. 91, 9213-921. (1994)

6. Gaczynska, M., Rock, K. L. \& Goldberg, A. L. Nature 365, 264-267 (1993).

7. Driscoll, J., Brown, M. G., Finley, D. \& Monaco, J. J. Nature 365, 262-264 (1993).

8. Aki, M. et al. J. Biochem. 115, 257-269(1994).

9. Van Kaer, L. et al. Immunity 1, 533-541 (1994)

\section{Design and synthesis of an ultraviolet-transparent nonlinear optical crystal $\mathrm{Sr}_{2} \mathrm{Be}_{2} \mathrm{~B}_{2} \mathrm{O}_{7}$}

\section{Chuangtian Chen, Yebin Wang, Baichang Wu, Keche Wu, Wenlun Zeng \& Linhua Yu}

Nature 373, 322-324 (1995)

THE name of the fourth author of this Letter was misspelt and is Kechen Wu. 